\title{
PENINGKATAN HASIL BELAJAR BIOLOGI SISWA MELALUI PENERAPAN MODEL PEMBELAJARAN KOOPERATIF TIPE GROUP INVESTIGATION
}

\author{
Asrianty Mas'ud \\ Program Studi Pendidikan Biologi, Fakultas Tarbiyah dan Keguruan UIN Sunan Gunung Djati, \\ Bandung 40614 \\ Email: anthyhanah@gmail.com
}

\begin{abstract}
Abstrak. Group investigation adalah salah satu tipe pembelajaran kooperatif yang menekankan pada partisipasi, aktivitas, dan melibatkan siswa dalam merencanakan, menentukan topik maupun cara menginvestigasi. Pembelajaran tipe group investigation juga dapat melatih siswa untuk menumbuhkan kemampuan berfikir mandiri. Penelitian ini bertujuan untuk: Meningkatkan hasil belajar biologi siswa dengan menerapkan model pembelajaran kooperatif tipe group investigation. Jenis penelitian ini adalah penelitian tindakan kelas yang dilakukan sebanyak dua siklus. Instrumen penelitian berupa tes hasil belajar. Data dianalisis secara kuantitatif dengan persentase. Hasil penelitian menunjukkan bahwa hasil belajar biologi siswa meningkat dari siklus I ke siklus II sebesar 58,62\% siswa yang tuntas belajar.
\end{abstract}

Kata kunci: pembelajaran kooperatif, group investigation, hasil belajar.

\begin{abstract}
Investigation group is a type of cooperative learning which stresses on the participation, activeness, and involves students in planning, determining the topic as well as the way to investigate. An investigation group learing type also guides students to think independently. The study aims was increasing students' learning outcome in Biology with group investigation learning model. This study is a classroom action research conducted in two cycles. The result of the study reveal that students' learning in Biology improves $58.62 \%$ from cycle I to cycle II for students' learning completeness.
\end{abstract}

Keywords: group investigation, learning outcome, cooperative leraning

\section{PENDAHULUAN}

Pendidikan merupakan hal yang sangat penting bagi bangsa, sehingga kemajuan dan mutu pendidikan menjadi hal yang mutlak untuk terus dipikirkan. Peran guru sangat dibutuhkan dalam upaya meningkatkan mutu pendidikan. Oleh karena itu, guru harus senantiasa meningkatkan kemampuan profesionalismenya dan meningkatkan pemahamannya terhadap siswa (Mulyasa, 2006). Demikian halnya dengan siswa juga diharapkan memegang peranan penting dalam menentukan pencapaian tujuan pendidikan, terutama partisipasi aktif dalam proses pembelajaran di kelas. Pada hasil belajar siswa kelas X SMA Negeri 1 Binamu khususnya untuk mata pelajaran biologi yang masih terbilang rendah. Hal ini berdasarkan informasi yang diperoleh dari guru mata pelajaran biologi SMA Negeri 1 Binamu yang dilihat dari nilai yang diperoleh siswa pada ulangan harian, dimana nilai rata-rata mata pelajaran biologi untuk kelas $\mathrm{X}_{1}$ yaitu hanya $50 \%$ siswa dari 29 orang jumlah siswa kelas $\mathrm{X}_{1}$ yang tuntas belajar dan selebihnya harus remedial karena nilai yang diperoleh tidak mencapai KKM yaitu 65 (berdasarkan kriteria nilai ketuntasan siswa SMA Negeri 1 Binamu). 


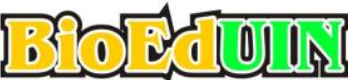

Jurnal Program Studi Pendidikan Biologi

Rendahnya hasil belajar siswa SMA Negeri 1 Binamu pada pelajaran biologi, selain disebabkan karena model pembelajaran yang digunakan oleh guru yang masih menggunakan metode yang bersifat konvensional juga disebabkan karena mata pelajaran biologi yang dianggap sulit oleh siswa. Biologi adalah ilmu yang memuat objek kajian yang kompleks. Selain itu, pelajaran biologi banyak menggunakan istilah-istilah latin yang susah untuk dipahami oleh siswa.

Oleh karena itu, penerapan model, pendekatan, strategi, metode dalam proses pembelajaran perlu mendapat perbaikan sehingga dapat menimbulkan interaksi timbal balik antara guru dan siswa. Seorang guru harus mampu menyajikan materi dengan menerapkan model yang mampu mengubah suasana belajar menjadi asyik dan menyenangkan, sehingga dapat meningkatkan minat belajar siswa. Berdasarkan masalahmasalah tersebut, guru dituntut untuk lebih inovatif dalam menentukan model pembelajaran. Tugas utama guru adalah membelajarkan siswa, yaitu mengkondisikan siswa agar belajar aktif sehingga potensi dirinya (kognitif, psikomotor dan afektif) dapat berkembang dengan maksimal. Agar hal tersebut di atas dapat terwujud, guru seyogianya menerapkan model pembelajaran yang bervariasi sehingga terhindar dari rasa bosan dan tercipta suasana belajar yang nyaman dan menyenangkan.

Group investigation adalah model pembelajaran yang melibatkan siswa sejak perencanaan, baik dalam menentukan topik maupun cara untuk mempelajarinya melalui investigasi. Model pembelajaran ini menuntut para siswa untuk memiliki kemampuan yang baik dalam berkomunikasi maupun dalam keterampilan proses kelompok (group process skills). Para siswa memilih sub topik yang ingin dipelajari dan topik yang biasanya telah ditentukan guru, selanjutnya siswa dan guru merencanakan tujuan, langkah-langkah belajar berdasarkan sub topik dan materi yang
p-ISSN : 2338-7173

e-ISSN : 2615-0417

(Februari), Vol. (8), No.(1)

dipilih. Kemudian siswa mulai belajar dengan berbagai sumber belajar baik di dalam ataupun di luar sekolah, setelah proses pelaksanaan belajar selesai mereka menganalisis, menyimpulkan, dan membuat kesimpulan untuk mempresentasikan hasil belajar mereka di depan kelas (Isjoni, 2009).

Santyasa (2008) mengungkapkan pembelajaran kooperatif tipe group investigation didasari oleh gagasan John Dewey tentang pendidikan, bahwa kelas merupakan cermin masyarakat dan berfungsi sebagai laboratorium untuk belajar tentang kehidupan di dunia nyata yang bertujuan mengkaji masalah-masalah sosial dan antar pribadi.

Kajian dan pembahasan berkenaan dengan model pembelajaran tipe group investigation ini juga dikemukakan oleh Sudrajat (2009) yang berpandangan bahwa group investigation salah satu bentuk model pembelajaran kooperatif yang menekankan pada partisipasi dan aktivitas siswa. Tipe ini menuntut siswa untuk memiliki kemampuan yang baik dalam berkomunikasi maupun keterampilan proses kelompok. Model pembelajaran tipe group investigation dapat melatih siswa untuk menumbuhkan kemampuan berfikir mandiri. Beberapa hasil penelitian tentang penerapan group investigation diantaranya adalah; diperoleh kesimpulan sebagai berikut: hasil penelitian Hasan (2009) menunjukkan bahwa terjadi peningkatan hasil peserta didik selama tiga siklus dengan menggunakan model pembelajaran kooperatif tipe group investigation.

\section{METODE PENELITIAN}

Jenis penelitian ini adalah Penelitian Tindakan Kelas (Classroom Action Research) yang dilaksanakan dalam bentuk siklus. Metode dalam penelitian ini yaitu tindakan mencakup: (a) perencanaan (planning), (b) pelaksanaan tindakan (action), (c) observasi dan evaluasi (observation and evaluation), dan (d) refleksi (reflection). Rancangan 


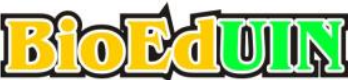

Jurnal Program Studi Pendidikan Biologi

penelitian tindakan kelas ini terdiri dari dua siklus. Penelitian ini dilakukan di SMA Negeri 1 Binamu yang berlokasi di Kecamatan Binamu, Kabupaten Jeneponto. Sebagai subjek dalam penelitian ini adalah kelas $\mathrm{X}_{1}$ dengan jumlah siswa sebanyak 29

\section{HASIL DAN PEMBAHASAN}

\section{Siklus I}

Berdasarkan hasil analisis deskriptif hasil belajar biologi siswa pada siklus I menunjukkan bahwa nilai tertinggi yang dapat dicapai siswa adalah 80 dan nilai terendah adalah 45 dengan nilai rata-rata 60,77 . Pengkategorian nilai hasil belajar biologi siswa pada siklus I dapat dilihat pada Tabel 1 di bawah ini.

Tabel 1. Kategori Nilai Hasil Belajar Biologi Siswa pada Siklus I

\begin{tabular}{|c|l|c|c|}
\hline $\begin{array}{c}\text { Interval } \\
\text { Skor }\end{array}$ & Kategori & $\begin{array}{c}\text { Jumlah } \\
\text { Siswa }\end{array}$ & $\begin{array}{c}\text { Persentase } \\
(\%)\end{array}$ \\
\hline $0-34$ & $\begin{array}{l}\text { Sangat } \\
\text { Rendah }\end{array}$ & 0 & 0 \\
\hline $35-54$ & Rendah & 8 & 27,58 \\
\hline $55-64$ & Sedang & 8 & 27,58 \\
\hline $65-84$ & Tinggi & 13 & 44,83 \\
\hline $85-100$ & $\begin{array}{l}\text { Sangat } \\
\text { Tinggi }\end{array}$ & 0 & 0 \\
\hline \multicolumn{2}{|c|}{ Jumlah } & 29 & 100 \\
\hline
\end{tabular}

Tabel 2, Kategori Ketuntasan Belajar Biologi Siswa pada Siklus I

\begin{tabular}{|c|l|c|c|}
\hline Nilai & Kriteria & $\begin{array}{c}\text { Jumlah } \\
\text { Siswa }\end{array}$ & $\begin{array}{c}\text { Persentase } \\
(\%)\end{array}$ \\
\hline $0-64$ & Tidak Tuntas & 17 & 58,62 \\
$65-100$ & Tuntas & 12 & 41,38 \\
\hline & Jumlah & 29 & 100 \\
\hline
\end{tabular}

Siklus II

Hasil analisis deskriptif hasil belajar biologi siswa pada siklus II menunjukkan bahwa nilai tertinggi yang dapat dicapai siswa adalah 87,5 dan nilai terendah adalah 65 dengan nilai rata-rata 71,12. Pengkategorian nilai hasil belajar biologi siswa pada siklus II dapat dilihat pada Tabel 3 di bawah ini. orang. Bahan yan digunakan berupa instrumen yang digunakan dalam penelitian ini adalah lembar tes hasil belajar. Tes hasil belajar yaitu dengan bentuk soal pilihan ganda sebanyak 40 butir soal

Tabel 3. Kategori Nilai Hasil Belajar Biologi Siswa pada Siklus II

\begin{tabular}{|c|l|c|c|}
\hline $\begin{array}{c}\text { Interval } \\
\text { Skor }\end{array}$ & Kategori & $\begin{array}{c}\text { Jumlah } \\
\text { Siswa }\end{array}$ & $\begin{array}{c}\text { Persenta } \\
\text { se }(\%)\end{array}$ \\
\hline $0-34$ & Sangat Rendah & 0 & 0 \\
\hline $35-54$ & Rendah & 0 & 0 \\
\hline $55-64$ & Sedang & 0 & 0 \\
\hline $65-84$ & Tinggi & 28 & 96,55 \\
\hline $85-100$ & Sangat Tinggi & 1 & 3,45 \\
\hline \multicolumn{2}{|c|}{ Jumlah } & 29 & 100 \\
\hline
\end{tabular}

Tabel 4. Kategori Ketuntasan Belajar Biologi Siswa pada Siklus II

\begin{tabular}{|c|l|c|c|}
\hline Nilai & Kriteria & $\begin{array}{c}\text { Jumlah } \\
\text { Siswa }\end{array}$ & $\begin{array}{c}\text { Persentase } \\
(\%)\end{array}$ \\
\hline $0-64$ & Tidak Tuntas & 0 & 0 \\
$65-100$ & Tuntas & 29 & 100 \\
\hline & Jumlah & 29 & 100 \\
\hline
\end{tabular}

Model pembelajaran kooperatif tipe group investigation adalah salah satu tipe pembelajaran yang menekankan pada partisipasi siswa untuk mencari sendiri materi (informasi) pelajaran yang akan dipelajari melalui bahan-bahan yang tersedia, misalnya dari buku pelajaran atau siswa dapat mencari melalui internet. Siswa dilibatkan sejak perencanaan, baik dalam menentukan topik maupun cara untuk mempelajarinya melalui investigasi (Santyasa, 2008). Penerapan model pembelajaran kooperatif tipe group investigation dianggap mampu meningkatkan hasil belajar biologi siswa kelas $\mathrm{X}_{1}$ SMA Negeri 1 Binamu Jeneponto.

Slavin (2009), mengemukakan bahwa hal penting untuk melakukan tipe group investigation adalah: (1) membutuhkan kemampuan kelompok, di dalam mengerjakan setiap tugas, setiap anggota kelompok harus mendapat kesempatan memberikan konstribusi. Dalam penyelidikan, siswa dapat mencari informasi dari berbagai informasi dari dalam maupun dari luar kelas. Kemudian, siswa mengumpulkan informasi yang 


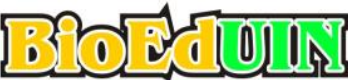

Jurnal Program Studi Pendidikan Biologi
p-ISSN : 2338-7173

e-ISSN : 2615-0417

(Februari), Vol. (8), No.(1) diberikan dari setiap anggota untuk mengerjakan lembar kerja. (2) rencana kooperatif, siswa bersama-sama menyelidiki masalah mereka, sumber mana yang mereka butuhkan, siapa yang melakukan apa, dan bagaimana mereka akan mempresentasikan proyek mereka di dalam kelas. (3) peran guru, guru menyediakan sumber dan fasilitator.

Peningkatan hasil belajar biologi siswa dapat terlihat dari rata-rata hasil belajar biologi siswa yang meningkat pada siklus II. Pada siklus I tes yang diberikan pada materi dunia tumbuhan (Plantae) setelah empat kali pertemuan, masih banyak siswa yang tidak tuntas yaitu sebanyak 17 orang siswa dengan persentase sebesar $58,62 \%$, ketidak tuntasan nilai siswa karena nilai yang diperoleh tidak mencapai nilai KKM yaitu 65, sedangkan yang tuntas dalam proses pembelajaran siklus I dengan materi dunia tumbuhan (Plantae) hanya 12 orang atau $41,38 \%$ dari 29 orang siswa yang mengikuti tes hasil belajar. Pada siklus II tes hasil belajar yang diberikan berhubungan dengan materi dunia hewan (Animalia), terjadi peningkatan yang sangat baik karena semua siswa berada dalam kategori tuntas. Nilai yang diperoleh telah mencapai atau bahkan lebih dari nilai KKM yang telah ditetapkan di SMA Negeri 1 Binamu Jeneponto yaitu 65. Persentase ketuntasan secara klasikal pada siklus II mencapai $100 \%$ atau meningkat sebesar $58,62 \%$ dari siklus I.

Rendahnya nilai hasil belajar pada siklus I ditandai dengan banyaknya siswa yang tidak tuntas, disebabkan karena pada siklus I siswa masih banyak yang beradaptasi dengan tipe group investigation yang diterapkan, kemampuan kerjasama dalam kelompok juga masih kurang sehingga beberapa siswa masih sedikit yang mendapatkan informasi mengenai materi yang dipelajari ataupun masih sangat rendahnya pemahaman terhadap materi yang disampaikan oleh guru karena perhatian beberapa siswa masih kurang fokus terhadap proses pembelajaran. Selain itu, adanya faktor ekstern yang ada pada lingkungan sekolah, dimana pertemuan- pertemuan awal siklus I banyak siswa yang tidak hadir sehingga mereka yang tidak hadir tidak mendapatkan informasi yang cukup tentang materi yang dipelajari. Banyaknya kegiatan beberapa siswa dalam ekstrakurikuler sekolah juga mempengaruhi hasil belajar siswa karena mereka tidak bisa konsentrasi sepenuhnya terhadap pelajaran karena kegiatan ekstrakurikuler yang padat pada awal-awal pertemuan.

Sudrajat (2009) mengemukakan adanya faktor-faktor yang mempengaruhi prestasi belajar siswa, yaitu: (1) faktor intern, yaitu faktor yang terdapat dalam diri individu itu sendiri, antara lain adalah kemampuan yang dimilikinya, minat dan motivasi serta faktorfaktor lainnya. (2) faktor ekstern, yaitu faktor yang berada di luar individu, di antaranya lingkungan keluarga, lingkungan sekolah, dan lingkungan masyarakat.Hasil penelitian yang dilakukan menunjukkan peningkatan hasil belajar biologi siswa. . Hasil penelitian tersebut menunjukkan hasil yang sama dengan penelitian yang dilakukan oleh peneliti sebelumnya yaitu Hasan (2009) yang menunjukkan bahwa terjadi peningkatan hasil peserta didik selama tiga siklus dengan menggunakan model pembelajaran kooperatif tipe group investigation. Demikian pula dengan hasil penelitian yang dilakukan oleh Mcklar (2008) menyatakan bahwa motivasi belajar siswa dengan menerapkan model pembelajaran kooperatif tipe group investigation menunjukkan hasil yang positif, terlihat dari peningkatan signifikan dari siklus I ke siklus II dari segi hasil pembelajaran.

\section{KESIMPULAN}

Berdasarkan hasil penelitian yang telah dilakukan dengan penerapan model pembelajaran kooperatif tipe group investigation pada kelas $\mathrm{X}_{1}$ SMA Negeri 1 Binamu Jeneponto, dapat disimpulkan bahwa terjadi peningkatan hasil belajar biologi siswa melalui penerapan model pembelajaran kooperatif tipe group investigation dari siklus I ke siklus II sebesar 58,62\%. 
:00:

Jurnal Program Studi Pendidikan Biologi

\section{DAFTAR PUSTAKA}

Hasan S. (2009). Model Cooperative Learning Tipe Group Investigation untuk Meningkatkan Hasil Belajar pada Mata Pelajaran Perawatan dan Perbaikan Sistem Refrigerasi. Skripsi. Bandung: FPTK UPI.

Isjoni. (2009). Cooperative Learning. Bandung: Alfabeta

Mcklr. (2008). Penerapan Pembelajaran Kooperatif Model Group Investigation untuk Meningkatkan Motivasi dan Hasil Belajar Siswa pada Mata Diklat. (http://one.indoskripsi.com/judulskripsi/skripsi-lainnya/penerapan-
p-ISSN : 2338-7173

e-ISSN : 2615-0417

(Februari), Vol. (8), No.(1)

pembelajaran-kooperatif-model-groupinvestigation-untuk-meningkatkanmotivasi-dan-has)

Mulyasa. (2006). Kurikulum yang Disempurnakan, Pengembangan Standar Kompetensi Dasar. Bandung: Remaja Rosadakarya.

Sudrajat, A. (2009). Pembelajaran Metode Group Investigation. (http://journal.uny.ac.id/index.php/jpms/ article/viewFile/173/76)

Slavin, R.E. (2009). Cooperative Learning. Bandung: Nusa Media. 